\title{
Translation Study on Figurative Rhetoric in Folding Beijing From the Perspective of Skopos Theory*
}

\author{
REN Rui, GUO Zhi-li, ZENG Jia-li, ZHANG Le-le \\ Northeastern University, Shenyang, China
}

\begin{abstract}
HAO Jing-fang, a Chinese writer with her novel Folding Beijing, was awarded the 2016 Hugo Award, the top award in global science fiction community, the second for Chinese science fiction writers after LIU Ci-xin for his The Three-Body Problem, which stroke a strong shockwave to the science fiction community around the world. It cannot be denied that Ken LIU's translation has played an irreplaceable role in the success of Folding Beijing. Unfortunately, there are a few studies on LIU's translation of Folding Beijing, let alone with Skopos theory. This paper refers to massive studies on it by scholars at home and abroad and is based on a careful reading of Folding Beijing, its translation counterpart and concludes that the translator adopts Skopos theory in translating figurative rhetoric by linking the three basic roles with the LIU's ideas on translation. This paper studies the translation on the figurative rhetoric in Folding Beijing and extracts so many typical sentences as to certify the flexible strategies and methods adopted by the author under Skopos theory, which conforms to the reading habit and taste of the target audience and provides a paradigm for the future translation of Chinese science fictions.
\end{abstract}

Keywords: Folding Beijing, Skopos theory, figurative rhetoric, translation strategy

\section{Introduction}

HAO Jing-fang studied in Center for Astrophysics of Tsinghua University from 2006-2008 and she graduated as a doctor of economics. She finished the composition of Folding Beijing at the end of 2012. She became the second Chinese writer to be awarded a Hugo Award for Best Novelette award at the 74th World Science Fiction Convention in the United States in 2016.

"I hope the real future will be brighter than my story" (HAO, 2016), the post-80s writer sincerely expressed her opinion on the world in her book at the 2016 Hugo Awards Ceremony held in Kansas City Convention Center.

Folding Beijing tells of the hard experience of a poor father who struggles to send his daughter to a decent kindergarten in futuristic Beijing. It is an allusion to the dilemma that some Chinese parents are dealing with, who spare no effort to send their children to receive a higher quality education. In this book, the author uses a

\footnotetext{
${ }^{*}$ Acknowledgements: This paper is sponsored by the research project of "Chunk-based Interpreting Teaching and Practice: A

Corpus-based Approach”, Northeastern University 2017-2018 Undergraduate Programs of Experiments and Practice.

REN Rui, associate professor, M.A., English Department, Northeastern University, Shenyang, China.

GUO Zhi-li, master candidate, English Department, Northeastern University, Shenyang, China.

ZENG Jia-li, master candidate, English Department, Northeastern University, Shenyang, China.

ZHANG Le-le, master candidate, English Department, Northeastern University, Shenyang, China.
} 
considerable amount of figurative rhetoric to add its artistic relish. The English rendering handled the figure of speech well and enjoyed popularity among the foreign market.

The first Asian writer LIU Ci-xin won a Hugo Award for Best Novel in 2015. The Three-Body Problem was the first part of a trilogy, bracing up China's science fiction community. And HAO’s Folding Beijing excited people again. Since science fiction has been peripheral in China for long and has always been regarded as children's literature, it cannot earn a place among mainstream literature and falls behind the West. Folding Beijing was improvised in Chinese. It was translated into English. Thus, it is more difficult for Folding Beijing to attract foreign readers. Yet, HAO Jing-fang's masterpiece has been embraced by the foreign market.

This paper studies the figurative translation strategies adopted by Ken LIU under the guidance of Skopos theory, mainly analyzing the figurative rhetoric in the novel. The study of the rendering of Folding Beijing may draw some inspirations to future translation of Chinese sci-fic work.

\section{A Brief of the Skopos Theory}

Skopos theory, as the backbone of German school of functionalist translation theory, is based on theory of action and intercultural communication. In Vermeer's model, translation is considered as a purposeful action, which is conceived to communicate across cultural and language barriers. It is pointed out that the transmitters should not lay emphasis on "equivalence" or the source text, but the anticipatory function of the translation in the translated language and cultural context.

German school of functionalist translation theory stemmed from 1970s. The four major proponents of the theory were Reiss, Vermeer, Manttari, and Nord. Katharina Reiss was an experienced translator and translation teacher. Vermeer and Nord were her students.

In 1978, Hans Vermeer freed from the fetters of traditional translation of "equivalence” by publishing $A$ Framework for a General Theory of Translation. He put forward Skopos theory and suggested making the Skopos of the target text the first rule. Reiss and Vermeer (1984) expounded the theory in Groundwork for a General Theory of Translation in 1984. In 1997, Nord (2001) gave a systematic expatiation of functionalist theory in Translating as a Purposeful Activity: Functionalist Approaches Explained. She added loyalty rule on the basis of moral requirements of translators.

From the perspective of functionalist translation theory, the process of translation involves many agents, not only the original author, translator, and target receiver, but also the client and the user of the translation. The initiator influences the process of translation more than the original author for the former one gives "translation tenor" which guides the whole translation process and defines the aim, using time, place, occasion, media and the communicative function of the translation, etc. When the translator receives the "translation tenor", according to the specific translation purpose, he would adopt proper translation strategies and started to transfer language and context to achieve translation. It is no doubt that the translator also plays a key role in the process of translation and bridges the initiator/commissioner and the user of the translation. The initiative and work of the translator determine if the translation requirements can be met and translation purpose can be achieved. The Skopos theory emphasizes the initiative of the translator and allows the translator use different translation strategies and methods based on the "translation tenor". 
The Skopos theory just regards the source text as an offer of information. The aim of translation is dominated by the client's commission. If necessary, the translator can adjust or modify the purpose.

Three rules of Skopos theory include:

(1) The TT (Target Text) must be internally coherent;

(2) The TT must be coherent with the ST (Source Text);

(3) The TT is determined by its Skopos.

\section{Detailed Analysis of the Figurative Rhetoric Translation in Folding Beijing}

\section{Translation Strategies Abiding by the Skopos Rule}

As is known by all, Skopos theory highlights the purpose of the translation. In order to meet this end, the Skopos rule was produced. The Skopos rule is at the top status in a translation. And nearly every translation method is relevant to it. And every strategy can make sense as long it meets the Skopos rule. In order to win a place in foreign market, the translator has to rewrite and adjust something in the ST that foreign readers may be confused or disgusted. Thus, the Skopos of the translation should be making the translation acceptable among the foreign readers and let them know more about China.

Since the Skopos was determined, the translator knows how to adopt omission and addition.

In this part, some examples will be demonstrated to observe how the translator abides by the Skopos rule.

\section{Omission}

(1) ST: “.....老刀对此毫无抵抗力, 他就像被舞台上的灯光层层围绕着, 只看到一片耀眼。” (HAO, 2012, p. 3)

TT: “...Lao Dao was dazzled as though surrounded by stage lights”. (LIU, 2015, p. 8)

"Tangtang had loved music since she was an eighteen-month-old. Every time she heard music in the streets, her face lit up and she twisted her little body and waved her arms about in a dance. She looked especially cute during those moments”. It is the root why Lao Dao was so fascinated and determined to risk of injury or imprisonment to deliver posts in order to send her to a premium kindergarten. And this sentence is describing his mood at those moments. Ken LIU just used one word “dazzled” to express Lao Dao's feelings and omitted the front and latter part of the sentence.

(2) ST: “不远不近的距离, 就像遥望西山或是海上的一座孤岛。”(HAO, 2012, p. 5)

TT: “The distance was perfect for taking in the whole city, like gazing at an island in the sea”. (LIU, 2015, p. 15)

Owing to the break in the highway was outside the Seventh Ring Road, but all the change occurred within the Sixth Road. So the truck drivers can witness the rotation every morning. But the author rewrote the sentence and deleted "the Mount West", avoiding confusing the target receivers.

\section{Addition}

(1) ST: “散场的舞厅器物凌乱, 像女人卸了妆。” (HAO, 2012, p. 19)

TT: "The deserted banquet hall after the party looked messy and grubby, like a woman who took off her makeup after a long, tiring day”. (LIU, 2015, p. 61)

Ken LIU added "after a long, tiring day” when he was translating the sentence. And this addition was even better than the source text. It outspoken the underlying meaning of the source sentence, so it made the rendering more lucid to the foreign readers. 
(2) ST: “小床散发出催眠气体, 四周立起围栏, 然后从地面脱离, 地面翻转, 床像一只篮子始终保持 水平。”(HAO, 2012, p. 20)

TT: "The bed released a cloud of soporific gas and extended rails on all sides; then it rose into the air. As the ground and everything on the ground turned, the bed would remain level, like a floating cradle”. (LIU, 2015, p. 66)

The translator added "on all sides" and "and everything on the ground" to make the target readers clearer about the sentence. The details he added made readers learn the meaning better.

\section{Translation Strategies Abiding by the Coherence Rule}

In Skopos theory, the coherence rule is also known as intra-textual coherence. The coherence rule requires the translator must make TT coherent and interpretable to the target text receiver's situation. To achieve this, the translator should cater to reading habits of TT readers. Ken LIU made a great effort to this regard. In Folding Beijing's rendering, the reorganization of sentences is obvious according to coherence rule. The following part gives some examples to show how they are done.

Switching of sentences

(1) ST: “食客围着塑料桌子, 埋头在酸辣粉的热气腾腾中, 饿虎扑食一般, 白色蒸汽遮住了脸。油炸 的香味弥漫。” (HAO, 2012, p. 1)

TT: "Customers packed the plastic tables at the food hawker stalls, which were immersed in the aroma of frying oil. They ate heartily with their faces buried in bowls of hot and sour rice noodles, their heads hidden by clouds of white steam”. (LIU, 2015, p. 2)

(2) ST: “他知道自己仍然是数字。在5128万这个数字中, 他只是最普通的一个。” (HAO, 2012, p. 20)

TT: "He knew that he was nothing more than a figure. He was but an ordinary person, one out of 51,280,000 others just like him”. (LIU, 2015, p. 66)

The translator knew both Chinese and English expressions well, so he changed the order of the sentences and achieved coherence in translation.

\section{Splitting of sentences}

(1) ST: “两旁狼吞虎咽的饥饿少年围绕着他。” (HAO, 2012, p. 1)

TT: “A group of hungry teenagers squatted around him, devouring their food”. (LIU, 2015, p. 3)

(2) ST: “老刀的父亲靠强健的意志在汹涌的人流中抓住机会的细草, 待人潮退去, 留在干涸的沙滩 上, 抓住工作机会, 低头俯身, 艰难浸在人海和垃圾混合的酸朽气味中, 一干就是二十年。” (HAO, 2012, p. 6)

TT: “Strong-willed, Lao Dao's father had held fast onto the thin reed of opportunity as the tide of humanity surged and then receded around him, until he found himself a survivor on the dry beach. His father had then kept his head down and labored away in the acidic rotten fetor of garbage and crowding for twenty years”. (LIU, 2015, p. 18)

\section{Translation Strategies Abiding by the Fidelity Rule}

The fidelity rule is also called inter-textual coherence which means that coherence must exist between the TT and the ST. In other words, the information cannot be fabricated by the translator. It should be in line with the ST. Even though the fidelity rule is at the lowest status in the hierarchical order of the three rules, it does not mean 
it can be ignored at easy cost. In fact, Ken LIU took high notice of preserving the original information and flavor of the ST. He would rather adopt literal translation compared with free translation. Also, in this section, some shortcomings are pointed out, such as over translation and pretermission.

\section{Literal translation}

Most of the renderings by Ken LIU were literal translation. Ken LIU has indicated that he would try his best to recur the content and meaning of the source text. So he prefers literal translation at the most time.

ST: “步行街一端的小推子开始收拾, 人群像用棍子搅动的池塘里的鱼, 修一下散去。” (HAO, 2012, p. 2)

TT: "The peddlers at the other end of the road began to pack up their wares, and the crowd, like fish in a pond disturbed by a stick, dispersed”. (LIU, 2015, p. 4)

The translation was consistent with the source text. The sentence was easy to understand, so it can be translated by literal translation method.

ST: “钢筋砖块合拢的声音连成一片, 像出了故障的流水线。” (HAO, 2012, p. 4)

TT: "The sound of steel and masonry folding, grating, colliding filled the air, like an assembly line grinding to a halt”. (LIU, 2015, p. 13)

The author just translated according to the source sentence. However, the using of several gerunds_-“grating, colliding, and grinding” makes the rendering more outstanding.

ST: “直到建成的日子高楼如活人一般站立而起，他们才像惊呆了一样四处奔逃，仿佛自己生下了一 个怪胎。”(HAO, 2012, p. 6)

TT: "Finally, when the completed building stood up before them like a living person, they had scattered in terror, as though they had given birth to a monster”. (LIU, 2015, p. 18)

\section{Free translation}

(1) ST: “司机们就在困倦与饥饿中欣赏这一幕无穷循环的城市戏剧。” (HAO, 2012, p. 5)

TT: “The Truck drivers, tired and hungry, admired the endless cycle of urban renewal”. (LIU, 2015, p. 16)

In the source text, the author compared the unfolding of the city to an opera. The translator did not use the word "opera" which appeared in the source text. He paraphrased it as "renewal". The smart conversion can make the target readers understand the meaning better.

(2) ST: “食客围着塑料桌子, 埋头在酸辣粉的热气腾腾中, 饿虎扑食一般, 白色蒸汽遮住了脸。油炸 的香味弥漫。” (HAO, 2012, p. 1)

TT: "Customers packed the plastic tables at the food hawker stalls, which were immersed in the aroma of frying oil. They ate heartily with their faces buried in bowls of hot and sour rice noodles, their heads hidden by clouds of white steam”. (LIU, 2015, p. 2)

\section{Conclusion}

Folding Beijing itself and its translation are both hugely successful. This paper has admirably achieved the goal of exploring Ken LIU's figurative rhetoric translation strategies with the combination of Skopos theory. As a translator, in field translation, he could not just be influenced by a single translation theory. Nevertheless, from the perspective of the requirements of Skopos theory, Ken LIU's rendering is mainly in line with the theory. His translation ideology is consistent with Skopos theory's basic rules. Conversely, it can be deduced that Skopos theory can be a criterion of the quality of a translation. 


\section{References}

HAO, J. F. (2012). Folding Beijing. Retrieved from https://uncannymagazine.com/article/folding-beijing-2/

LIU, K. (Trans.). (2016). 北京折 叠 Nolding Beijing). Retrieved from https://wenku.baidu.com/view/2a83310ffab069dc512201e7.html

Nord, C. (1991). Skopos, loyalty and translational conventions. Target, 3(1), 91-109.

Nord, C. (2001). Translating as a purposeful activity: Functionalist approaches explained. Shanghai Foreign Language Education Press.

Nord, C., \& Taber, M. (1969). The theory and practise of translation. Leiden: Brill.

Reiss, K. (2004). Translation criticism: The potentials and limitations. Shanghai: Shanghai Foreign Language Education Press.

Reiss, K., \& Vermeer, H. J. (1984). Groundwork for a general theory of translation. Tubingen: Niemeyer.

REN, R. (2010). On translator's visibility. Journal of Northeastern University (Social Science), 12(6), 540. 